\title{
Recurrent Glioma
}

National Cancer Institute

\section{Source}

National Cancer Institute. Recurrent Glioma. NCI Thesaurus. Code C132506.

The reemergence of a glioma after a period of remission. 